\title{
Mound bedding in a sponge-rich Coniacian chalk, Bornholm, Denmark
}

\author{
NANNA NOE-NYGAARD AND FINN SURLYK
}

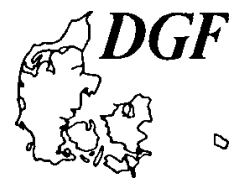

Noe-Nygaard, N. \& Surlyk, F.: Mound bedding in a sponge-rich Coniacian chalk, Bornholm, Denmark. Bull. geol. Soc. Denmark, vol. 34, pp. 237-249, Copenhagen, December, 20th, 1985. https://doi.org/10.37570/bgsd-1985-34-19

The Coniacian Arnager Limestone is exposed on the island of Bornholm in the Baltic Sea. The formation is composed of marly silica-rich chalk with a very sparse shelly macrofauna. Impressions of siliceous spon-ges occur in great abundance but flint is virtually absent. The chalk is intensely bioturbated and only the latest and deepest burrows have left recognisable trace fossils. Mapping of the irregular bedding reveals that deposition took place in a complex system of low mud-mounds. Distance between top of mounds and adjacent lows is $6-8 \mathrm{~m}$, the amplitude is up to 1-2 $\mathrm{m}$, and maximum dip of the flanks is $5-10^{\circ}$. The mounds seem to be circular to oval in plan view. The association of mounds and high density siliceous sponge fau-nas suggests that the sponges and perhaps the spicule mats of dead decaying sponges were effective in baffling and trapping the fine-grained chalk ooze and clay which was swept by slow bottom currents. The currents seem to have intermittently reached sufficient strength to cause scouring of mound flanks, and mound formation was thus probably dependant of the delicate balance between production of carbonate ooze, current velocity and persistency, and of environmental conditions favourable to dense growth of sili-ceous sponges. The Arnager Limestone mounds are geometrically similar to Upper Maastrichtian and Da-nian bryozoan chalk mounds of Denmark and Upper Turonian and Santonian chalk mounds of Nor-mandy. If the mounds were caused, in part, by sponge baffling they represent a previously undescribed type of mound from the Cretaceous of north-west Europe.

N. Noe-Nygaard, Institut for Historisk Geologi og Palaontologi, Øster Voldgade 10, DK-1350 København K, Denmark; F. Surlyk, Grønlands Gologiske Undersøgelse, Øster Voldgade 10, DK-1350 København K, Denmark, August 1st, 1985.

Low, commonly asymmetric lime mud-mounds are known from several levels in the Upper Cretaceous and Danian of north-west Europe (e.g. Cheetham 1971; Kennedy \& Juignet 1974; Rasmussen 1971; Rosenkrantz \& Rasmussen 1960; Thomsen 1976, 1977, 1983). Only the Danian examples have received detailed study and were interpreted by Thomsen $(1976,1977,1983)$ as caused by the baffling effects of a dense but low bryozoan cover. To date, no carbonate mudmounds from the Upper Cretaceous of northwest Europe have been ascribed to sponge baffling. In this paper we describe a system of interwoven mud-mounds from the Coniacian Arnager Limestone, and suggest that the argillaceous chalk ooze was in part baffled and trapped by siliceous sponges and spicule mats.

\section{Occurrence and stratigraphy}

The Arnager Limestone is exposed on the south coast of the island of Bornholm, a complexly faulted horst situated in the Fenno-Scandian Border Zone (fig. 1). The age of the formation is not precisely known but evidence from ammonites, belemnites (Christensen 1985) and foraminifera (Douglas \& Rankin 1969) suggests a Middle Coniacian Age.

The Arnager Limestone disconformably overlies the lower Middle Cenomanian Arnager Greensand and has a composite basal conglomerate (Bromley 1979). The Arnager Limestone is overlain by the Lower and Middle Santonian Bavnodde Greensand. The thickness is $12-20 \mathrm{~m}$ and the only good exposure is in the cliff immediately west of the harbour of Arnager. The formation and its fauna were briefly monographed by Ravn (1918) but have otherwise been only cursorily treated in the literature.

\section{Lithology}

The basal bed of the Arnager Limestone is a 20 $\mathrm{cm}$ thick conglomerate composed of composite 


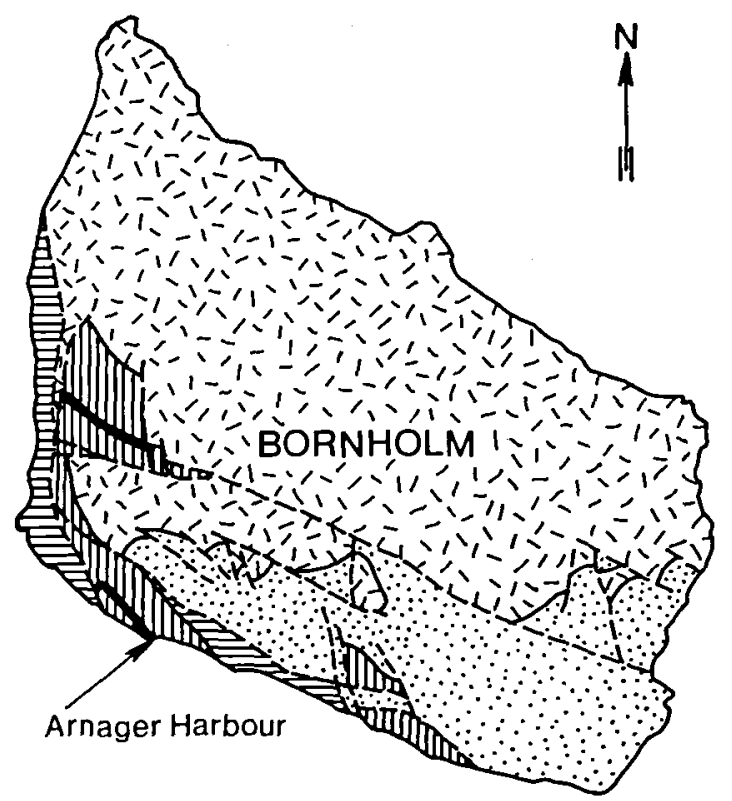

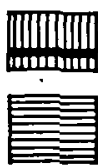

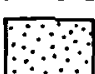

i-1

- Fault
Cretaceous

Arnager limestone

Jurassic

Lower Paleozoic

Precambrian basement

Fig. 1. Map showing the position of the locality described in the text, and the distribution of the Arnager Limestone.

glauconitized and phosphatized pebbles of chalk, glauconitic chalk, and greensand (fig. $3 \mathrm{~A}$ ). Detailed description of this basal conglomerate will be presented in a subsequent paper. A sketch showing burrows penetrating down into the underlying Arnager Greensand was given by Bromley (1979).

The remaining part of the formation is lithologically uniform and consists of marly, silicarich, grey chalk. The carbonate content is relatively low, mainly between $55-65 \%$. The sediments contain abundant corroded coccoliths as well as foraminifera. The silica is mainly present in the form of cristobalite lepispheres (Fig. 2). A very characteristic feature observed in thin sections and scanning electron microscope is the great amount of needle-shaped pores with a diameter of about $0.01-0.05 \mathrm{~mm}$ probably representing dissolved opaline sponge spicules. The walls of the holes are commonly lined with lepispheres. The essentially circular cross sections of the holes indicate that dissolution took place after compaction of the surrounding sediment. The marly chalk is normally described as white, but on fresh, wet surfaces it shows medium to dark grey shades.

The Arnager Limestone is strongly bioturbated and several generations of burrows can be recognized at most levels (fig. 3). The irregular, diffuse, smeared outlines of the older burrows (fig. 4B) suggest that the bottom was soft, plastic and perhaps thixotropic at the time they were formed. Subsequent sedimentation resulted in compaction and stabilisation and emplacement of well preserved burrows with sharp boundaries. The bottom had in the meantime moved upwards and probably remained soft (compare Ekdale \& Bromley 1983). The Arnager burrow assemblage includes Zoophycos, Chondrites, Planolites, Teichichnus (?), and Thalassinoides, commonly with a green lining of the burrow wall.

The shelly fauna of the Arnager Limestone is of very low density and diversity. Ravn (1918) reported only 26 species from the chalk in the cliff at Arnager. The identification of several of these species was uncertain and the majority of the species was represented by only or a few specimens. The benthic fauna includes large specimens of the foraminifer Flabellina sp. and limid, pectinid, ostreid and spondylid bivalves. Large specimens of inoceramid bivalves are the most abundant shelly macrofossils. A few small rhynchonellid brachiopod species also occur.

In contrast to the sparse shelly invertebrate 


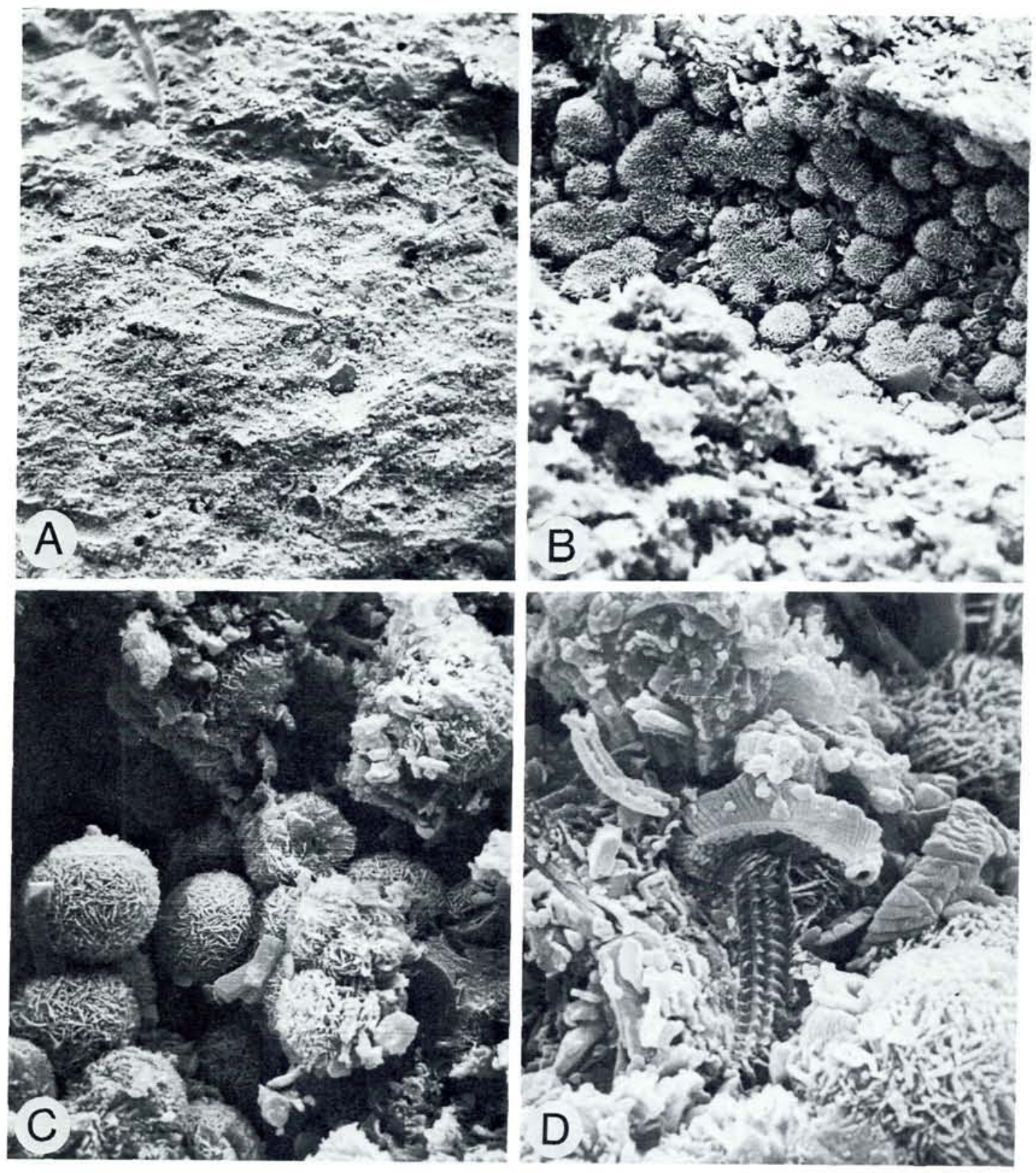

Fig. 2. Scanning electron micrographs of fracture surfaces of Arnager Limestone. A. Fracture surface showing numerous longitudinal and cross sections of needle-shaped pores probably after dissolved sponge spicules, x 65 .

B. Cristobalite lepispheres on the wall of one of the needle shaped pores on a, x 650 .

C. Cristobalite lepispheres formed in the pores of the chalk, $x 2700$.

D. Corroded coccoliths and coccolith platelets, cristobalite lepispheres, x 6530.

fauna siliceous sponges and spicules are found in great abundances (fig. 3B). The sponge fauna has not yet been taxonomically treated, but a large number of vase-shaped, low, conical, and branched forms occur, commonly reaching 10-20 $\mathrm{cm}$ in height. The sponges are found throughout the cliff section; they are rare to absent in some beds, while they occur in high densities in other beds. Three bedding plane counts gave 23,43 , and 74 sponges per $\mathrm{m}^{2}$. The counts only included 

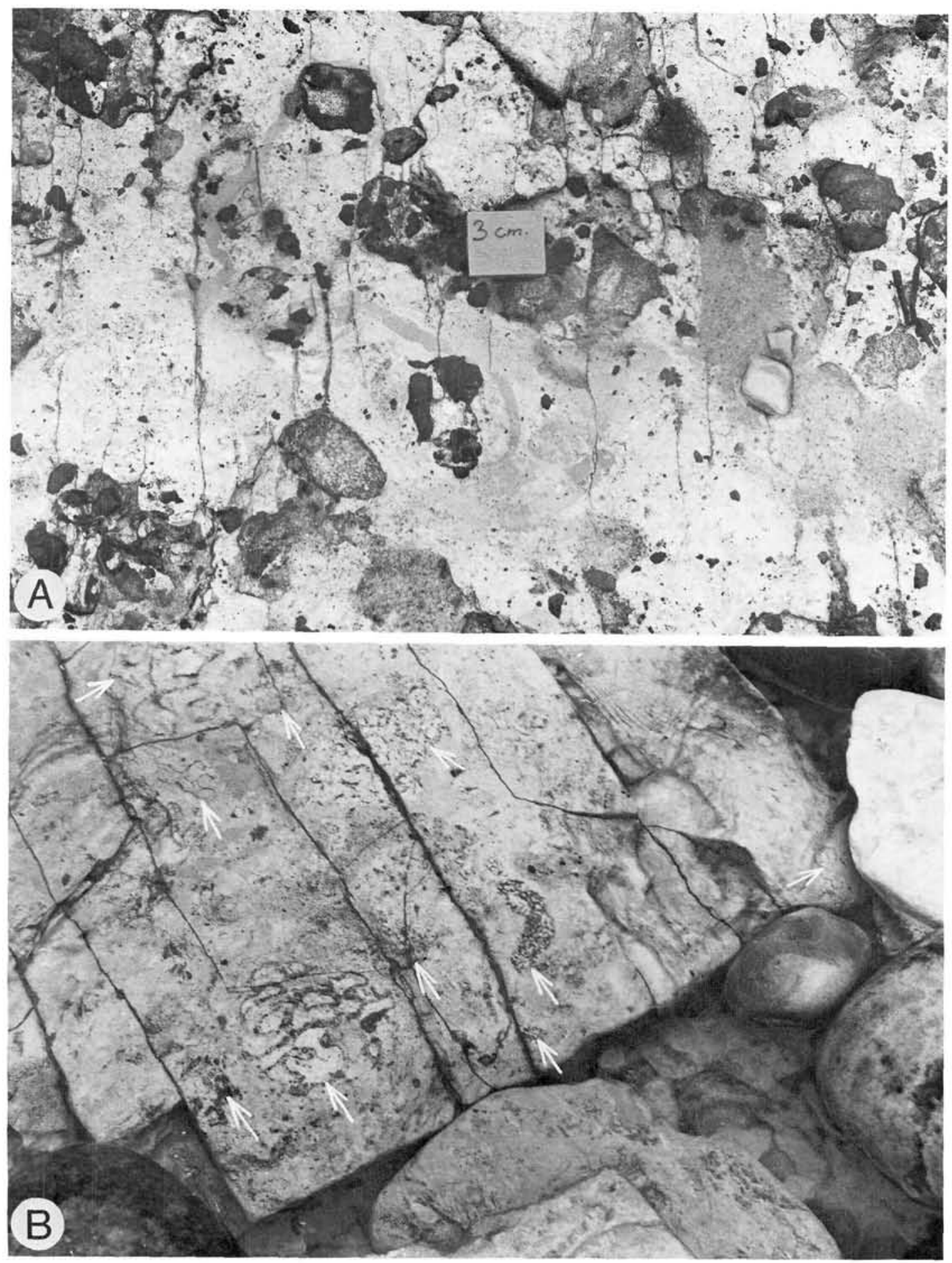

Fig. 3. A. Bedding plane exposure of upper surface of the basal hiatus conglomerate of the Arnager Limestone. Note the composite nature of the larger pebbles and the fong grey burrows between the pebbles.

B. Bedding plane of Arnager Limestone showing the high density of siliceous sponges (arrows). 


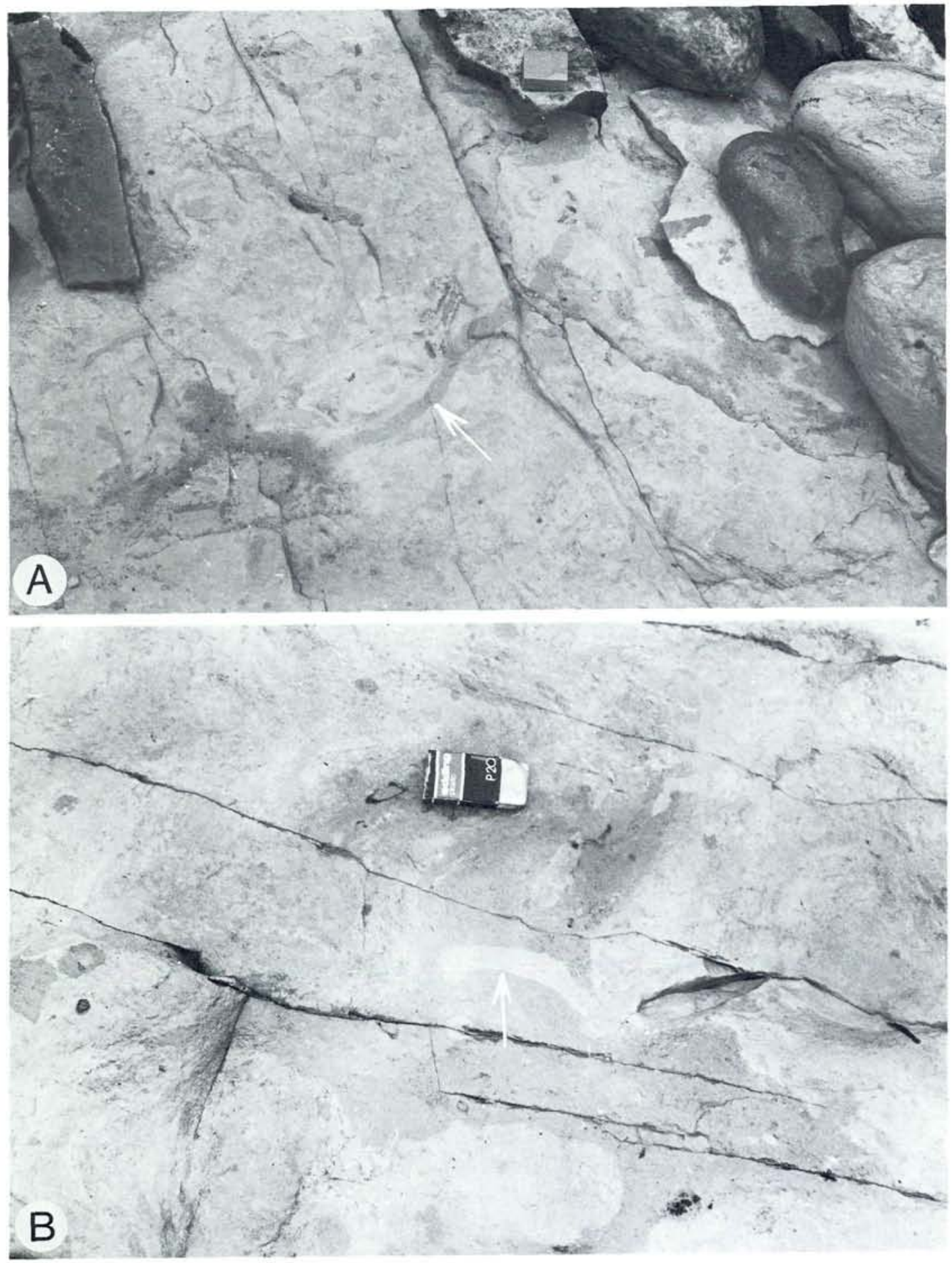

Fig. 4. A. Long, irregular late stage burrows cross-cutting slightly older burrows of same type ( $3 \mathrm{~cm}$ eraser on stone for scale). B. Bedding plane of Arnager Limestone showing smeared out, cloudy bioturbated nature of the sediment with clearly defined late stage burrow (arrow). ( $3 \mathrm{~cm}$ eraser for scale). 

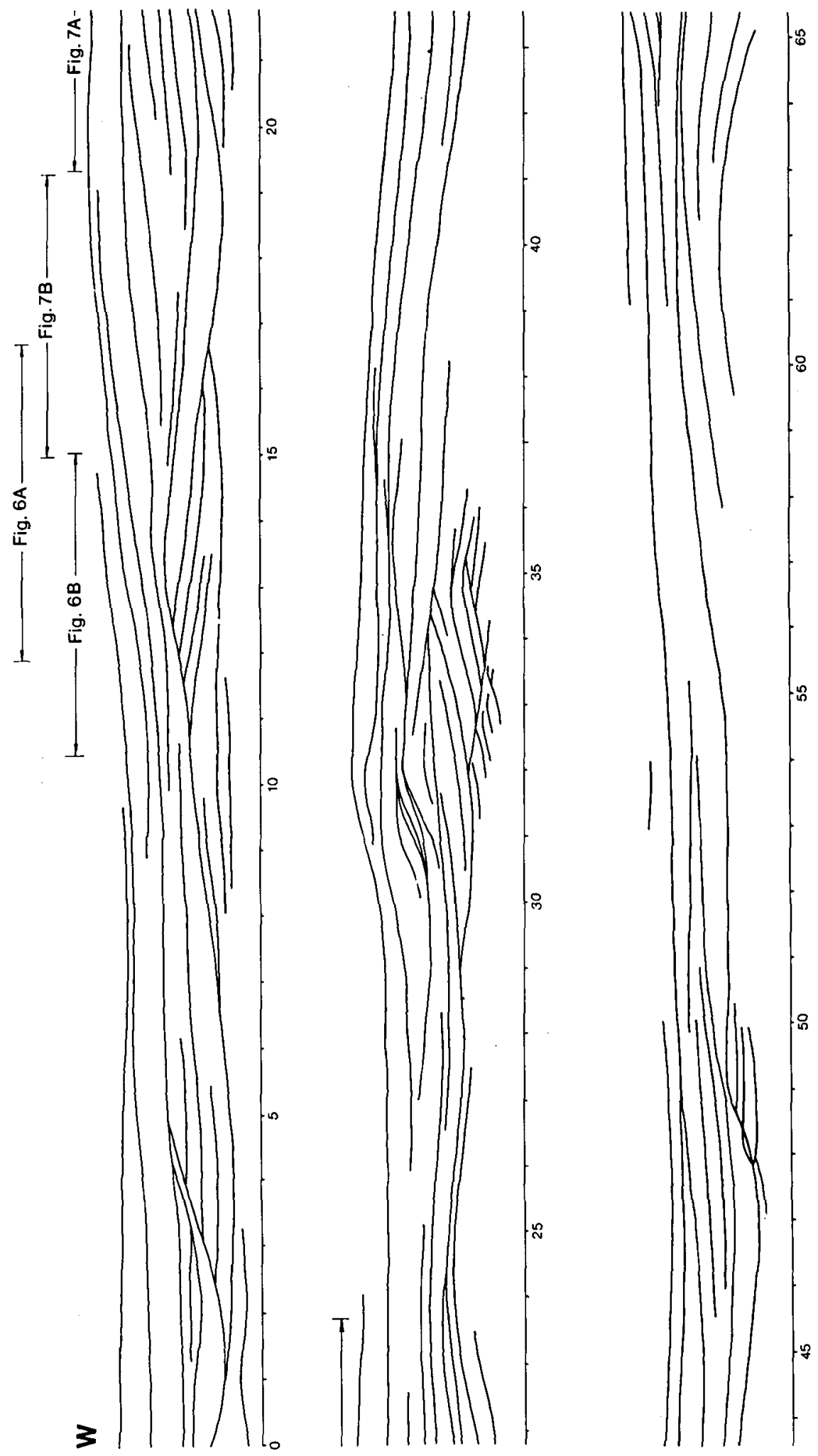


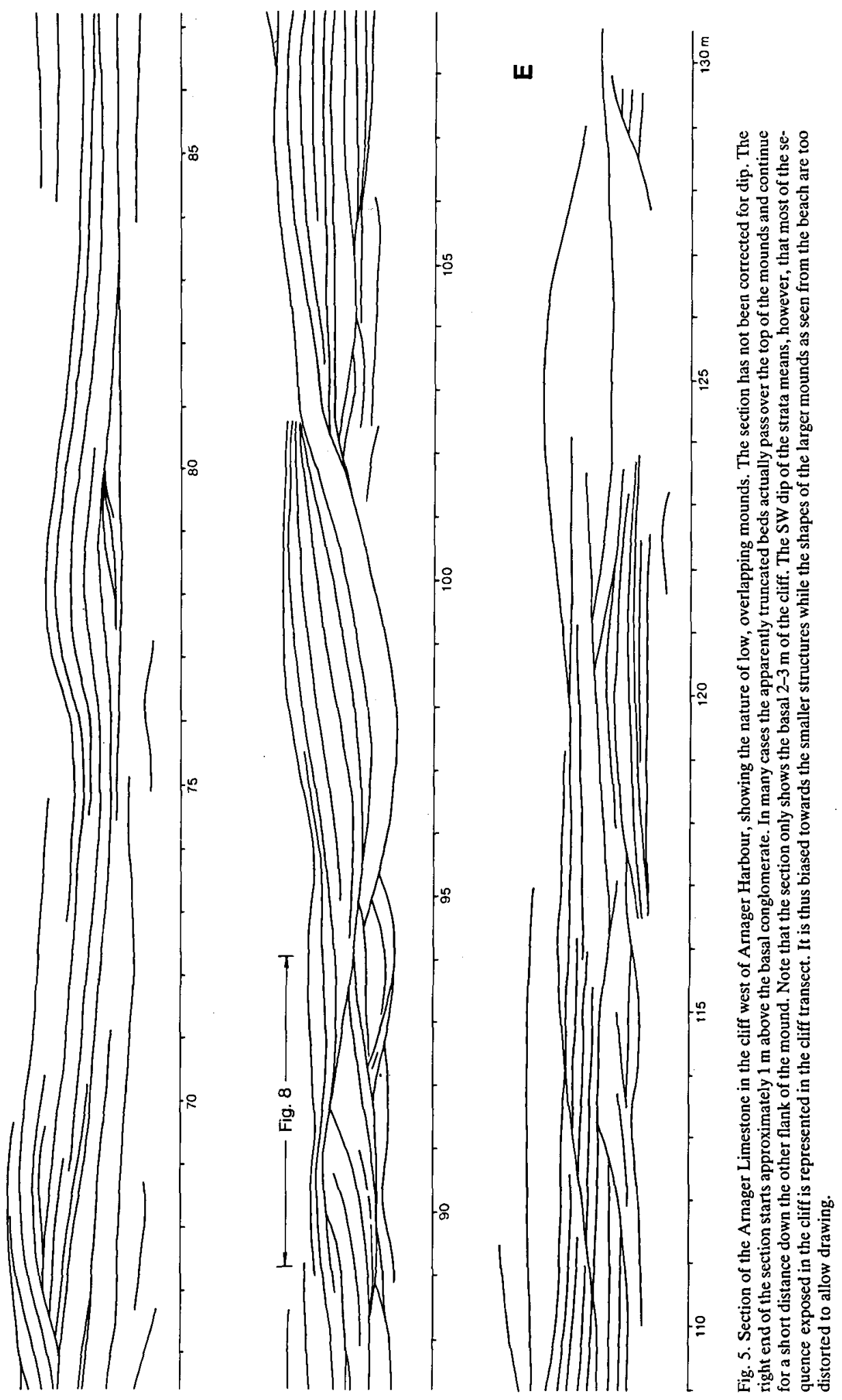


large, well preserved, clearly recognizable specimens. It is not known whether the paucity of sponges in other levels reflect their original absence, or a loss of fossil sponges through taphonomic processes.

\section{Bedding}

In earlier accounts on the sedimentary fabric of the Arnager Limestone (Ravn 1918, Rasmussen 1967) it was stressed that distinct bedding is virtually absent; only irregular joints and cracks were noted. Examination in cloudy weather preferably after a period of heavy rain reveals, however, that the formation shows a distinct, wavy and hummocky bedding (figs. 5-8).

A $130 \mathrm{~m}$ long section of the lower 2-3 $\mathrm{m}$ of the cliff was mapped during July 1984 (fig. 5). The higher stratigraphic levels were not easily accessible at this locality so that a distorted view of the bedding was visible from the beach. Almost the entire sequence exposed in the cliff is, however, represented in figure 5 due to the low dip towards south-west (strike $131^{\circ}$, dip ca. $5^{\circ}$ towards SW). Most bedding planes are curved, convex or concave-up, and form low angles with the basal Arnager Limestone conglomerate, which indicates the horizontal plane at the time of deposition (figs. 6-8).

The individual beds vary in thickness from about 5 to about $30 \mathrm{~cm}$. Bed boundaries occur as fissures in the outcrop; they appear to follow the highly compacted fabric of irregularly alternating horizons of more or less marly and silica-rich chalk. Figures 5-8 show that deposition took place in a system of complex mounds, outlined by flank beds which dip up to $5-10^{\circ}$. The base of the mounds is commonly concave-up, and dip of flank beds seems to be in all directions although the two-dimensional nature of the cliff section makes it impossible to compile a non-biased set of measurements. Only the two dip directions parallel to the cliff face can be clearly seen. The mounds are broadly symmetric in external crosssection (fig. 6). The distance between mound summit and adjacent low is 2 to $8 \mathrm{~m}$, while the original topographic amplitude is up to $1-2 \mathrm{~m}$. The highest parts of the sequene exposed at the top of the western end of the section exhibit larger mounds with distances from summit to low of about $15 \mathrm{~m}$ and heights of about $3 \mathrm{~m}$. Beds commonly thicken towards the top of the mounds. It is a characteristic feature that beds drape both mound summits and lows, wedge out or show off-shoots up the flanks of the adjacent mounds in a manner reminiscent of hummocky cross-stratification. Internal asymmetry in the arrangement of beds within a mound analogous to foreset beds or cross-strata as well as a systematic direction of mound overlap is commonly observed. Sharp concave-up boundaries occur at several locations (e.g. at $0-5 \mathrm{~m}$ in fig. 5). These boundaries may represent erosive surfaces caused by occasional scouring by strong bottom currents. We have, however, never observed lags overlying the surfaces or marked differences in grain-sizes across them. The concave-up boundaries may thus more likely represent surfaces of non-deposition on mounds dominated by pronounced uni-directional accretion. Careful tracing of the apparently truncated beds reveals that the beds in many cases continue across the top of the mound to the other side of the mound where they are much thinner (fig. 8). In these examples erosion can thus be excluded as a mound forming agent and the internal asymmetry of bedding appear to reflect uni-directional accretion. It is, furthermore, significant that virtually all dipping beds whether "truncated" or not show a marked upwards thickening reaching maximum thickness at the summit of the hummock or mound (figs. 6 , 8).

\section{Interpretation}

The mounds show a superficial resemblance to current and wave produced bed forms and structures such as mega-ripples, sandwaves, largescale trough cross-stratification and hummocky cross-stratification. These interpretations can, however, be rejected. The marly, silica-rich chalk was far too fine-grained to be deposited in cross-stratified mega-ripples by bottom currents. The initially semifluid sediment consistency as revealed by the smeared, diffuse outlines of the first formed trace fossils also exlude grain-bygrain deposition by bottom traction currents. The high degree of bioturbation which is characteristic of the sequence shows that the sedimentation rate was slow which is also inconsistent with trac- 


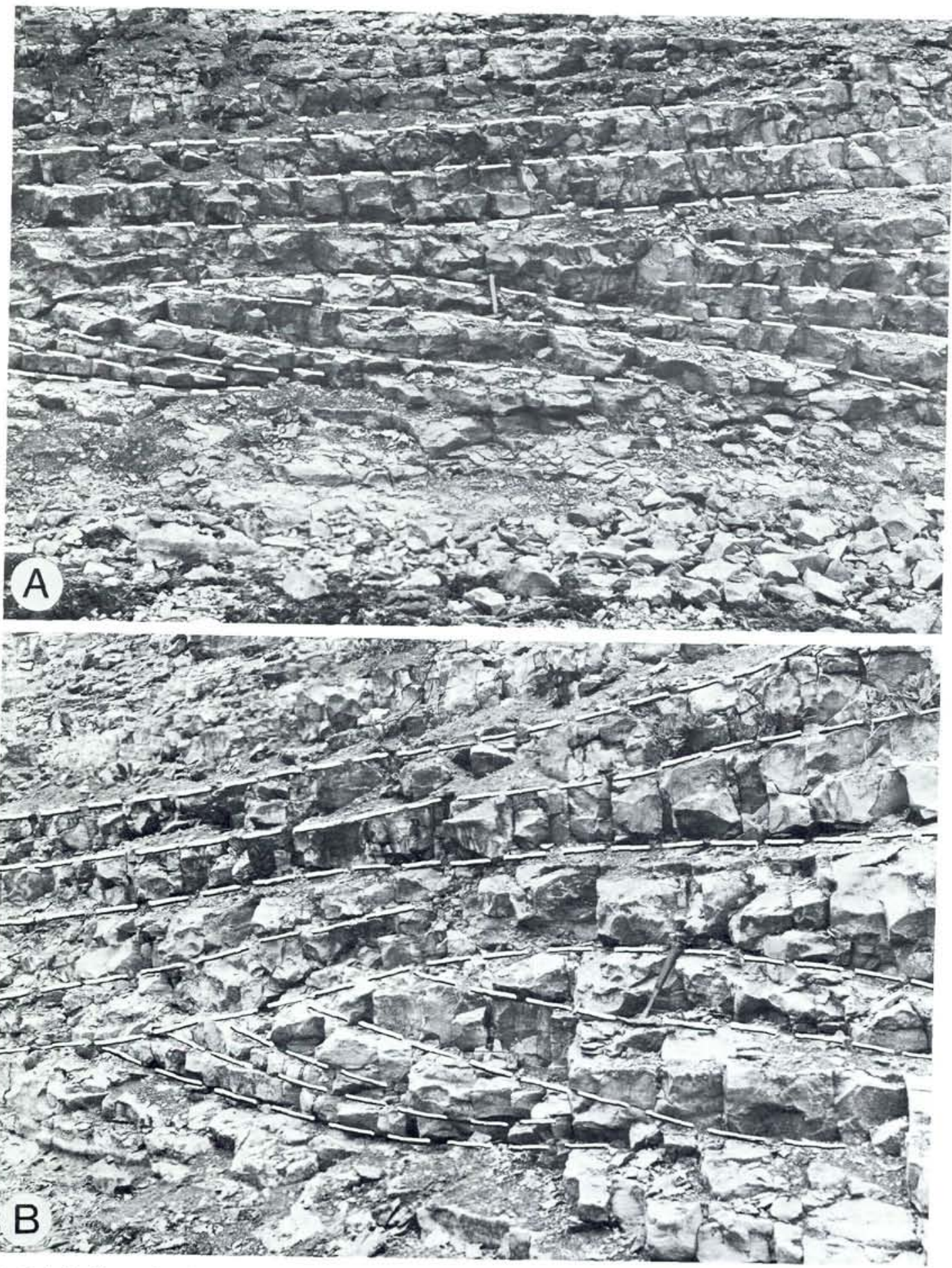

Fig. 6. A. Small mound to the left of hammer overgrown by left flank of large mound rising to the right of hammer.

B. Detail of small mound on A. Note the externally symmetric shape of the mound and the internal asymmetry. 
tion current deposition of large beds forms. Finally, most of the sponges of the Arnager Limestone are Hexactinellida. Today these are considered characteristic of extremely quiet conditions and deeper, clear water. This is inconsistent with strong current and wave action. In Late Paleozoic and Early Mesozoic times they occurred, however, in shallow water and the bathymetric implications of their occurrence in the Arnager Limestone is not clear.

The bedding was thus formed by lateral accretionary growth of mounds on the sea-floor. The occurrence of concave-up surfaces truncating beds may represent non-depositional mound flanks or perhaps interruption of mound growth associated with some erosion during storms. The largest mounds do not show the strong asymmetry of the smaller steep-sided mounds, and they seem to reflect a preferential upwards rather than lateral accretion. The mounds are geometrically closely related to the chalk mounds described from the Upper Maastrichtian and Danian chalks of Stevns Klint and Karlstrup (Rosenkrantz 1966; Rosenkrantz \& Rasmussen 1960, Surlyk 1969, 1972, 1979, 1982, Surlyk \& Birkelund 1977) and in particular from the Danian at Karlby Klint, East Jylland (Thomsen 1976, 1977, 1983) and Limhamn, Sweden (Cheetham 1971). These mounds are composed of bryozoan chalk with wackestone and packstone texture, and most authors have assumed that they were formed by biohermal growth caused by the sediment trapping effect of erect bryozoan colonies. The Danian bioherms studied in detail by Thomsen $(1976,1977,1983)$ consist of about $30 \%$ bryozoans in a chalk matrix. The bioherms are asymmetric internally, as revealed by thick inclined beds showing uni-directional accretion on the up-current flank, whereas beds become thin or in some cases appear to be truncated on the down-current flank. They thus have the main geometric features in common with the mounds described in the present paper.

Thomsen $(1976,1977,1983)$ recognized two distinct facies in the Danian mounds at Karlby Klint, a packstone with fine bryozoan fragments characteristic of the basins and the least steep down-current flanks of the biohermal ridges, and a wacke- and packstone with coarse bryozoans characteristic of the crests and steeper up-current flanks. The differences in the size of the bryo- zoan fragments were shown by Thomsen (1976, $1977,1983)$ to be due to adaptations to changes in water movement rather than significant sizesorting transport. The main growth in the bioherms was on the up-current side where the higher current velocities over the flank and crest favoured a dense bryozoan cover which was able to trap and bind the matrix. On the down-current flank the currents were slower and less favourable for growth, and the ability of the bryozoans to bind the sediment was correspondingly slower (Thomsen 1976).

The Arnager mounds have a number of important features in common with the Maastrichtian and Danian bryozoan mounds. Both groups are composed of fine-grained chalk although the Arnager Limestone is more marly and silica-rich, and much poorer in a benthic shelly fauna. Both groups of mounds have a relatively low amplitude, an asymmetrical internal structure reflecting lateral accretionary growth, and formed mound fields rather than occurring as isolated structures.

Kennedy and Juignet (1974) described chalk mounds of the same general type from the Upper Turonian and Santonian of Normandy. These mounds were also interpreted as bioherms, but Kennedy \& Juignet (1974) were unable to find evidence for potentially baffling organisms and proposed a plant cover, either of algae or marine angiosperms as a possibility.

The main geometric difference between the Arnager mounds and the mounds described in the literature is one of scale, the Arnager mounds being somewhat smaller in dimensions. In this respect they compare well, however, with the top Maastrichtian mounds in Stevns Klint (Rosenkrantz 1966, Surlyk 1979, 1982, Alvarez et al. 1984).

The mounds described here from the Arnager Limestone can thus be compared with bioherms or organic build-ups. The baffling organisms were possibly siliceous sponges (fig. 3B). Baffling may have been aided by dense spicule mats formed during the decay of dead sponges (suggestion by R. G. Bromley 1984). SEM microscopy shows that the Arnager Limestone contains innumerable needle shaped pores which most likely represent dissolved sponge spicules (fig. 2). If this interpretation of the pores is correct minute sponge spicules formed dense mats on the sea- 




Fig. 7. A. Left flank of large mound. Hammer in centre of photo for scale.

B. Complex interfingering of four low amplitude mounds. 


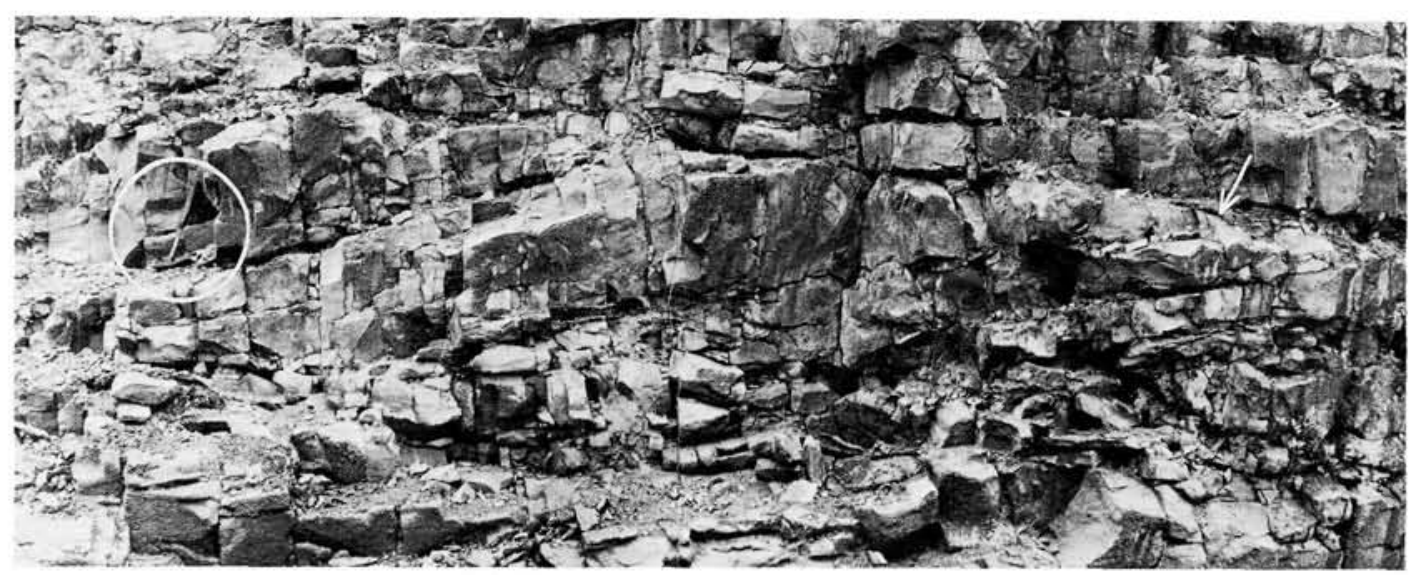

Fig. 8. Large asymmetric mound showing accretion to the left, overlapped on the right flank by relatively low amplitude mound. Hammer to the left for scale (encircled). Arrow shows where a thick bed continues from the left flank of the mound over the crest and down the right flank where it becomes very thin. floor. These mats may have had the double effect of stabilizing the sea-bottom and trapping fine sediment particles. They may also have prevented settling of a shelly epi- and infauna. Organisms with calcite skeleton occurred only rarely and always in very low densities. They are, however, well preserved where they occur and selective calcite dissolution seems not to have taken place. They can thus be excluded as potential mound builders. It is important to note that essentially the same mound shapes appear to have been caused by the sediment trapping of bryozoans and sponges. In the former case the resulting sediment is a bryozoan wacke- or packstone, while it is a marly silica-rich micrite in the latter case. The internal asymmetry of bedding shows lateral accretion for the smaller mounds and upwards plus lateral growth for the larger mounds. By analogy with Thomsen's (1976, 1977, 1983) conclusions from the Danian bryozoan mounds it is suggested that the direction of accretion corresponds to the up-current side of the mounds.

\section{Conclusions}

1) The marly silica-rich chalk of the Coniacian Arnager Limestone of Bornholm was deposited in a system of low, overlapping mud-mounds.

2) The mounds possessed an original topographic relief on the sea-floor with an amplitude of up to $1-2 \mathrm{~m}$ and a distance from summit to ba$\sin$ of 2 to $8 \mathrm{~m}$.

3) The mounds are roughly symmetrical in cross-section, and internally asymmetrical as revealed by the bedding. Growth was strongly unidirectional in the smaller mounds, while the larger mounds are characterized by pronounced upwards and lateral, asymmetric growth. The occurrence of concave-up bedding planes which sharply truncate earlier bedding suggests that erosion by currents also played a role in producing a hummocky sea-floor.

4) The mounds contain an extremely sparse calcite shelled macrofauna, whereas molds of siliceous sponges occur in great densities in many horizons (up to $74 / \mathrm{m}^{2}$ counted).

5) The sponges formed dense thickets on the sea-bottom and may have acted as baffling orgamisms trapping fine sediment particles carried by slow currents.

6) Sponge spicules probably formed mats on the sea-floor. These mats stabilized the bottom, trapped sediment particles and prevented settling of a shelly fauna.

7) The mounds of the Arnager Limestone are geometrically similar to Upper Maastrichtian and Danian bryozoan mounds from Stevns Klint and eastern Jylland, and of upper Turonian and Santonian mounds of the Normandy. If the interpretation of the Arnager Limestone mounds as formed by the baffling effect of dense growths of sil- 
iceous sponges and sponge spicule mats is correct they represent a new type of organic mound shaped build-up in the Upper Cretaceous : of north-west Europe.

Acknowledgements. This study was supported by grants to Finn Surlyk from the Danish Natural Science Research Council and to Nanna Noe-Nygaard from the Geological Central Institute, University of Copenhagen. We acknowledge the use of Gravgærde, the geological field station of the University of $\mathrm{Co}$ penhagen. We thank R. G. Bromley, E. G. Kauffman and E. Thomsen for critically reading the manuscript and $A$. Matter for discussion. Vibeke Hermansen, Nina Turner, Bodil Sikker Hansen, O. B. Bertelsen, J. Fuglsang Nielsen and J. Lautrup contributed with highly appreciated technical assistance in the preparation of the manuscript.

\section{Dansk sammendrag}

1) Arnagerkalken (Coniacien, Bornholm) består af merglet kiselholdigt skrivekridt. Det blev aflejret i et komplekst system af lave, overlappende banker.

2) Bankerne fremstod ved deres dannelse med et tydeligt topografisk relief pả havbunden. Amplituden kunne blive op til 1-2 $\mathrm{m}$, mens den vandrette afstand fra banketop til -trug var 2-8 m.

3) Bankerne var stort set symmetriske i ydre tværsnit, men var internt asymmetrisk opbygget, hvilket fremgår af lagstillingen.

4) Bankerne indeholder en yderst sparsom calcitskallet makrofauna, mens aftryk af kiselsvampe er meget hyppige $i$ mange niveauer (op til $741 \mathrm{~m}^{2}$ målt).

5) Kiselsvampene dannede således tætte bevoksninger på havbunden og kan måske have fungeret som fælder for fine sedimentpartikler, der blev transporteret af langsomme havstrømme. Forekomsten af konkav-op lagflader, der afskarer tidligere aflejrede lag, representerer formodentlig erosive begivenheder.

6) Kiselsvampespikler dannede tætte måtter på havbunden. Disse måtter stabiliserede bunden, virkede som fælder for fine sedimentpartikler og hindrede væksten af en normal, kalkskallet bundfauna.

7) Arnagerkalkens banker minder $i$ deres opbygning og form om Øvre Maastrichtien og Danien bryozobankerne fra Stevns Klint og Karlby Klint, og om Øvre Turonien og Santonien bankerne fra Normandiet. Hvis Arnagerkalkens banker dannedes ved kiselsvampes sedimentfangende virkning representerer de en ny type biogene banker i Nordvesteuropas Øvre Kridt.

\section{References}

Alvarez, W., Kauffman, E. G., Surlyk, F., Alvarez, L. W., Asaro, F. \& Michel, H. V. 1984: Impact theory of mass extinctions and the invertebrate fossil record. Science 223: 1135-1141.

Bromley, R. G. 1979: Field meeting in southern Scandinavia 18-28, September 1975. Proc. Geol. Assoc. 90: 1135-1141.
Cheetham, A. H. 1971: Functional morphology and biofacies distribution of Cheilostome Bryozoa in the Danian Stage (Palaeocene) of southern Scandinavia. Smithsonian Contrib. Palaeobiol. 6: 87.

Christensen, W. K. 1985: The Albian to Maastrichtian of southern Sweden and Bornholm, Denmark: A review. Cretaceous Research, 5: 313-327.

Douglas, R. G. \& Rankin, C. 1969: Cretaceous planktonic foraminifera from Bornholm and their zoogeographic significance. Lethaia, 2: 185-217.

Ekdale, A. A. \& Bromley, R. G. 1983: Trace fossils and ichnofabric in the Kjølby Gaard Marl, uppermost Cretaceous, Denmark. Bull. geol. Soc. Denmark, 31: 107-119.

Kennedy, W. J. \& Juignet, P. 1974: Carbonate banks and slump beds in the Upper Cretaceous (Upper TuronianSantonian) of Haute Normandie, France. Sedimentology, 21: $1-42$.

Rasmussen, H. W. 1967: Det europæiske kontinent og lag fra jordens middelalder. In: Nørrevang A. \& Meyer, T. J. (eds.): Danmarks Natur, 83-102. Politikens Forlag.

Rasmussen, H. W. 1971: Echinoid and crustacean burrows and their diagenetic significance in the Maastrichtian-Danian of Stevns Klint, Denmark. Lethaia, 4: 191-216.

Ravn, J. P. J. 1918: Kridtaflejringerne på Bornholms sydvestkyst og deres fauna. 2. Turonet. Danm. geol. Unders. 2. rk., 31: 1-37.

Rosenkrantz, A. 1966: Die Senon/Dan-Grenze in Dänemark. Ber. deutsch. Ges. geol. Wiss. A, 11: 721-727.

Rosenkrantz, A. \& Rasmussen, H. W. 1960: South-Eastern Sjælland and Møn, Denmark. Int. Geol. Congress. 21 Sess. Norden 1960. Guide-book 1. Copenhagen.

Surlyk, F. 1969: A study on the articulate brachiopods of the Danish White Chalk (U. Campanian and Maastrichtian) with a review of the sedimentology of the white chalk and the flora and fauna of the Chalk Sea. Unpubl. Prize Dissertation, University of Copenhagen: 1-319 (In Danish).

Surlyk, F. 1972: Morphological adaptations and population structures of the Danish chalk brachiopods (Maastrichtian, Upper Cretaceous). Det Kongelige Danske Videnskabernes Selskab, 19 (2): 1-57.

Surlyk, F. 1979: Guide to Stevns Klint. In: Birkelund, T. \& Bromley, R. G. (eds.), Cretaceous - Tertiary boundary events. Symposium I. The Maastrichtian and Danian of Denmark. University of Copenhagen 1979: 164-170.

Surlyk, F. 1982: Upper Cretaceous and Danian outcrops in Scania and East Denmark. In: The Upper Cretaceous and Danian of NW Europe. Excursion: 069A. 26th International Geological Congress, Paris 1980: 31-62.

Surlyk, F. \& Birkelund, T. 1977: An integrated stratigraphical study of fossil assemblages from the Maastrichtian White Chalk of Northwestern Europe. In: Kauffman, E. G. and Hazel, J. E. (eds.), Concepts and methods of biostratigraphy. Dowden, Hutchinson \& Ross, Inc., Stroudsburg: 257-281.

Thomsen, E. 1976: Depositional environment and development of Danian bryozoan biomicrite mounds (Karlby Klint, Denmark). Sedimentology, 23: 485-509.

Thomsen, E. 1977: Relations between encrusting bryozoans and substrate: an example from the Danian of Denmark. Bull. geol. Soc. Denmark, 25: 133-145.

Thomsen, E. 1983: Relation between currents and the growth of Palaeocene reef-mounds. Lethaia, 16: 165-184. 